\title{
Trafic membranaire entre les voies de sécrétion et d'endocytose
}

\author{
par Bernard Hoflack \\ Institut de Biologie de Lille-1, rue du Professeur Calmette, 59021 Lille Cedex.
}

Reçu le 22 mars 2001

\section{RÉSUMÉ}

Le transport des protéines solubles et membranaires vers les compartiments endocytiques est un des mécanismes essentiels à l'homéostasie cellulaire (pour revue voir 1,2 ). Il permet tout d'abord d'adresser ces protéines vers les compartiments tardifs de la voie d'endocytose (endosomes tardifs et lysosomes) comme dans le cas de récepteurs du mannose 6-phosphate (pour revue voir 3) qui véhiculent les hydrolases acides des lysosomes, ou les glycoprotéines transmembranaires des membranes des lysosomes telles les glycoprotéines Lamp I ou Limp II. Il permet aussi d'adresser vers les compartiments endocytiques des molécules essentielles au bon fonctionnement de la défense immunitaire comme les molécules de classe II du complexe majeur d'histocompatibilité. Enfin, cette voie de transport est aussi utilisée par certaines glycoprotéines d'enveloppe de virus de la famille de l'Herpès et est donc essentielle à la biogenèse des particules virales. Il est actuellement admis que ce transport est assuré par des intermédiaires vésiculaires qui bourgeonnent du réseau trans-golgien et fusionnent avec les endosomes (pour revue voir 4).

Ces intermédiaires de transport sont recouverts de clathrine et de protéines d'assemblage tout comme ceux impliqués dans la première étape de l'endocytose. Ces complexes hétérotétramériques interagissent, d'une part avec la clathrine par l'intermédiaire de leur sous-unité $\beta$ et, d'autre part avec les signaux de tri (de type tyrosine ou dileucine) contenus dans les domaines cytoplasmiques des protéines transmembranaires par l'intermédiaire de leur sous-unité $\mu$. Ces protéines d'assemblage ou APs font donc le lien entre la clathrine et les protéines membranaires à transporter. Deux types des protéines d'assemblage sont impliqués dans le tri des protéines transmembranaires destinées à être transportées du réseau trans-golgien vers les endosomes : les complexes AP-1 et AP-3. Leur interaction avec les membranes est régulée par la petite GTPase ARF-1 (ADP ribosylation factor 1). Nos études ont montré tout d'abord que l'interaction des complexes AP-1 et AP-3 avec les membranes nécessite non seulement la GTPase ARF-1 mais aussi la présence du domaine cytoplas- mique des protéines membranaires destinées à être transportées. Ceci suggère fortement que le tri des protéines est couplé à la formation des intermédiaires de transport. Elles ont ensuite montré que les complexes AP-1 et AP-3 sont capables d'interagir avec différentes classes de protéines transmembranaires. Le complexe AP-1 interagit et donc assure le tri des récepteurs du mannose 6-phosphate, des molécules de classe II ou les glycoprotéines d'enveloppe des virus de l'herpès. Par contre, le complexe AP-3 interagit et assure le transport des glycoprotéines lysosomales Lamp I ou Limp II qui contiennent dans leur domaine cytoplasmique soit un motif de tri tyrosine soit dileucine comme celles qui interagissent avec le complexe AP-1. La nature des acides aminés formant ces signaux de tri ou celle des acides aminés situés dans les séquences adjacentes pourrait expliquer ces interactions sélectives entre les complexes AP-1, AP-3 et leur cargo (pour revue voir 5).

Afin de comprendre de façon plus approfondie, comment le tri des protéines membranaires et la formation d'intermédiaires de transport recouverts soit du complexe AP-1 soit du complexe AP-3 s'effectuent, nous avons suivi deux approches complémentaires. La première approche est fondée sur l'observation en vidéo microscopie de cellules vivantes exprimant de façon stable les récepteurs du mannose 6-phosphate étiquetés par la Green Fluorescent Protein (GFP). Ces études ont montré que les récepteurs du mannose 6-phosphate sont véhiculés par des intermédiaires tubulaires $(6 \mu \mathrm{m})$ de transport qui se détachent du réseau trans-Golgien, migrent le long de microtubules vers la périphérie cellulaire (vitesse $1 \mu \mathrm{m} / \mathrm{sec}$ ) et fusionnent ensuite avec de compartiments périphériques dont certains éléments sont accessibles à des marqueurs endocytiques. Cette dynamique est contrôlée par la GTPase ARF-1. La seconde approche que nous avons suivie est fondée sur l'utilisation de protéo-liposomes afin de reconstituer in vitro les interactions des complexes AP-1 et AP-3 avec des membranes artificielles dans lesquelles sont ancrés des peptides synthétiques correspondant aux domaines cytoplasmiques des protéines triées in vivo 
par les complexes AP-1 et AP-3. Nos premiers résultats montrent que le complexe AP-3 est recruté sur des protéoliposomes contenant le domaine cytoplasmique de Lamp I. Ce recrutement nécessite la présence du motif tyrosine intact contenu dans le domaine cytoplasmique de Lamp I et la petite GTPase ARF-1 qui peut être ajoutée sous forme de protéine recombinante myristoylée. Ce recrutement est spécifique du complexe AP-3 puisque les autres protéines de manteau participant à différents aspects du trafic membranaire, comme les complexes AP-1,
AP-2 impliqué dans l'endocytose ou COPI impliqué dans le transport entre le reticulum endoplasmique et le Golgi, ne sont pas recrutées par ces proteoliposomes. Si ces résultats renforcent la notion que le tri des protéines est couplé à la formation d'intermédiaires de transport, ils nous permettent d'envisager l'utilisation d'un tel système pour purifier et caractériser toutes les protéines accessoires qui avec les complexes AP-1, AP-3 et la clathrine participent au tri et au transport de protéines membranaires du réseau trans-Golgien vers les endosomes.

\section{SUMMARY Membrane traffic between the secretion and endocytosis pathways}

The transport of soluble and membrane proteins across endocytotic compartments is an essential mechanism of cellular homeostasis (see Rouille $e t$ al. 2000 ; Rohn et al., 2000, for reviews). It is responsible in the first place for addressing these proteins to the late compartments of the endocytosis pathway (late endosomes and lysosomes), as in the case of mannose-6 receptors (reviewed in Ludwig et al., 1995) which transport the lysosomal acid hydrolases, or the transmembrane glycoproteins of lysosomal membranes, such as glycoproteins Lamp 1 or Limp 1. It also mediates the endocytotic compartment addressing of molecules ensuring a correct immune function, such as major histocompatibility class II molecules. Finally this transport pathway is also used by some envelope proteins of the Herpes family viruses and, as such, is essential for the biogenesis of viral particles. This transport is admittedly performed by vesicular intermediates, which bud off from the transGolgi network, and fuse with endosomes (see review in Le Borgne and Hoflack, 1998a).

These transport intermediates are coated with clathrin and assembly proteins exactly like the ones implicated in the first step of endocytosis. These heterotetrameric complexes interact on one hand with clathrin through their $\beta$ subunit, and on the other hand with sorting out signals (of tyrosine or dileucine type) encoded in the cytoplasmic domains of transmembrane proteins through their $\mu$ subunit. These assembly proteins (APs) link clathrin and the membrane proteins that should be transported. Two types of assembly proteins are implicated in the sorting out of the transmembrane proteins, that are to be transported from the trans-Golgi network to the endosomes : the AP-1 and AP-3 complexes. Their interaction with membranes is regulated through the small GTPase ARF-1 (ADP ribosylation factor 1). Our first studies showed that the interaction of AP-1 and AP-3 complexes with membranes requires not only the ARF-1 GTPase but also the cytoplasmic domain of membrane proteins that are to be transported. This strongly suggests that protein sorting out is coupled with the formation of transport intermediates. Further studies showed that AP-1 and 3 are capable of interacting with various classes of transmembrane proteins. The AP-1 complex interacts with and thus ensures sorting out of mannose-6-phosphate receptors, of class II molecules or herpes virus envelope glycoproteins. In contrast, the AP-3 complex interacts with and ensures the sorting out of lysosomal proteins Lamp I and Limp II, which contain in their cytoplasmic domain either a tyrosine or a dileucine sorting out motif, like the proteins which interact with the AP-1 complex. Either the identity of the aminoacids which make up these sorting out signals or the identity of the amino-acids located in adjacent sequences might explain these selective interactions between complexes AP-1, AP-3 and their cargo (reviewed in L.e Borgne and Hoflack, 1998b).

In order to understand in depth how the sorting out of membrane proteins and the formation of transport intermediates coated with either AP-1 or AP-3 complex occur, we have used two complementary approaches. The first is based on the videomicroscopic observation of living cells, stably expressing mannose-6-phosphate receptors labelled with Green Fluorescent Protein (GFP). These studies have shown that mannose-6-phosphate receptors are ferried by tubular transport intermediates $(6 \mu \mathrm{m})$ which detach from the trans-Golgi network, migrate along microtubules to the cell periphery (at a speed of $1 \mathrm{~mm} / \mathrm{sec}$ ) and fuse with peripheral compartments, some of which are accessible to endocytotic markers. This dynamic process is controlled by GTPase ARF-1. The second approach we have implemented is based on the use of proteoliposomes in order to reconstitute in vitro the interactions between the AP-1 and AP-3 complexes and artificial membranes in which synthetic peptides are anchored, which correspond to the cytoplasmic domains of proteins sorted out in vivo by these complexes. Our first results show that the AP-3 complex is recruited on proteoliposomes which contain the cytoplasmic domain of Lamp I. This recruitment requires the intact tyrosine motif of 
Lamp I cytoplasmic domain and the small ARF-1 GTPase, which can be added as a recombinant myristoylated protein. This recruitment is specific of The AP-3 complex since the other coat proteins participating to various aspects of membrane traffic, like AP-1, AP-2 implicated in endocytosis, or COPI implicated in the transport between the endoplasmic reticulum and the Golgi, are not recruited by these pro-

\section{BIBLIOGRAPHIE}

Rouille Y., Rohn W., Hoflack B., Targeting of lysosomal proteins. Semin. Cell Dev. Biol., 2000, 11 (3), 165-171.

Rohn W.M., Rouille Y., Waguri S., Hoflack B., Bi-directional trafficking between the trans-Golgi network and the endosomal/lysosomal system. J. Cell Sci., 2000, 113 (Pt 12), 2093-2101. teoliposomes. While these results reinforce the notion that protein sorting out is coupled with the formation of transport intermediates, they allow us to consider using this system to purify and characterize all the accessory proteins that, with complexes AP-1, AP-3 and clathrin, participate in the sorting out and transport of membrane proteins from the trans-Golgi network to the endosomes.
Ludwig T., Le Borgne R. and Hofack B., Roles of mannose 6-phosphate receptors in lysosomal enzyme sorting, IGF II binding and clathrin-coat assembly. Trends Cell Biol., 1995. 5, 202-206

Le Borgne R., Hoflack B., Protein transport from the secretory to the endocytic pathway in mammalian cells. Biochim. Biophys. Acta., 1998, 1404 (1-2), 195-209.

Le Borgne R., Hoflack B., Mechanisms of protein sorting and coat assembly : insights from the clathrin-coated vesicle pathway. Curr. Opin. Cell. Biol., 1998, 10 (4), 499-503. 